\title{
SELF SERVING BIAS ANAK BERHADAPAN DENGAN HUKUM DI LEMBAGA PEMBINAAN KHUSUS ANAK KELAS II BANDUNG
}

\author{
Akung Wahyu Tri Wiyono \\ Politeknik Kesejahteraan Sosial bandung, wahyuakung123@gmail.com \\ Moch Zaenal Hakim \\ Politeknik Kesejahteraan Sosial Bandung, zaenal_hakim@poltekesos.ac.id \\ Dayne Trikora Wardhani \\ Politeknik Kesejahteraan Sosial Bandung, daynetrikora@gmail.com
}

\begin{abstract}
Self-Serving bias is a tendency to perceive oneselffavourably than another peoples. This research aimed to examine: 1) subject characteristics, 2) Self Serving attribution 3) Self Congratulatory Comparison, 4) Illusory Optimism, 5) False Consensus for Failings, and 6) Children in conflict with the law hopes. This research aimed to obtain in depth overview of selfserving bias children in the conflict with the law. So the result can be used to determine and identify the various risk that due to the occurrence of self-serving bias in children. Furthermore these findings can be used to design an effective guidance program for children. Informants in this study were nine people, namely five children in the conflict with the law and four as supporting informants. The method used in this research is case study qualitative method. Data sources used are primary data sources and secondary data sources. Determination of data sources in this research using purposive sampling techniques. Data collection techniques were in-depth interviews, participatory observation, and documentation study. The results showed that all children in the conflict with the law conducted self-serving bias with symptoms in the form of attributing positive things to themselves and negative things to others, considering themselves better than other children in various ways, having expectations that were not realistic, and have the wrong consensus on the crime committed and become children in the conflict with the law in juvenile detention center. researcher recommends that efforts should be made is handling self-serving bias through Cognitive Behaviour Therapy. Before individual therapy, children in the conflict with the law have to do therapeutic group therapy to improve self-development in terms of cognitive, emotional, psychosocial, and moral.
\end{abstract}

Keywords: Self Serving Bias, Children In Conflict With the Law, Lembaga Pembinaan Khusus Anak Kelas II Bandung.
Self Serving Bias adalah tendensi seseorang untuk menganggap dirinya lebih baik dibandingkan orang lain. Penelitian ini akan mengkaji tentang: 1) karakteristik informan, 2) Self Serving attribution (kesalahan dalam mengatribusi) 3) Self Congratulatory Comparison 
(menganggap diri lebih baik dibanding orang lain), 4) Illusory Optimism (optimisme yang tidak realistis), 5) False Consensus For Failings (kesalahan konsensus terhadap kegagalan), dan 6) Harapan Informan. Penelitian ini bertujuan mendapatkan gambaran mendalam self serving bias sehingga dapat digunakan untuk mengidentifikasi berbagai resiko munculnya self serving bias dan mengupayakan program pembinaan yang tepat. Informan penelitian ini sembilan orang yaitu lima anak berhadapan dengan hukum dan empat sebagai informan pendukung. Metode dalam penelitian ini adalah metode kualitatif studi kasus. Sumber data yang digunakan data primer dan data sekunder. Penentuan informan menggunakan teknik purposive sampling. Teknik pengumpulan data adalah wawancara mendalam, observasi partisipatif, dan studi dokumentasi. Hasil penelitian menunjukkan keseluruhan anak berhadapan hukum yang menjadi informan melakukan self serving bias dengan gejala-gejala berupa mengatribusikan hal positif kepada diri sendiri dan hal negatif kepada orang lain, menganggap dirinya lebih baik daripada anak didik yang lain dalam berbagai hal, memiliki harapan yang tidak realistis, dan memiliki konsenus yang salah terhadap tindak kejahatan yang dilakukan dan menjadi anak didik didalam lembaga pembinaan khusus anak. Melalui terapi kognitif perilaku dapat menurunkan perilaku self serving bias pada anak. Namun sebelum terapi individu terlebih dahulu anak berhadapan hukum melakukan terapi kelompok terapeutik guna meningkatkan perkembangan diri dalam hal konitif, emosional, psikososial, dan moral.

Kata Kunci: Self Serving Bias, Anak berhadapan dengan hukum, Lembaga Pembinaan Khusus Anak

\section{PENDAHULUAN}

Angka kriminalitas di Indonesia mengalami peningkatan setiap tahunnya. Kriminalitas tidak hanya dilakukan oleh orang dewasa namun juga dilakukan oleh anak-anak sehingga mereka terjerat dalam tindak pidana . Undang Undang Nomor 11 Tahun 2012 tentang Sistem Peradilan Pidana Anak menyebutkan bahwa Anak Berhadapan dengan Hukum $(\mathrm{ABH})$ adalah anak yang telah berumur 12 tahun tetapi belum berumur 18 tahun yang diduga melakukan tindak pidana. ABH meliputi anak sebagai pelaku, anak yang menjadi korban, dan anak yang menjadi saksi tindak pidana.

Komisi Perlindungan Anak Indonesia tahun 2018 menerima 1.434 pengaduan kasus $\mathrm{ABH}$. Peningkatannya tidak terlalu signifikan jika dibandingkan dengan tahun 2017 yang berjumlah 1.403 kasus. Jumlah Anak berdasarkan kasus yang masuk kedalam
Lembaga Pemasyarakatan Khusus Anak (LPKA) yaitu kasus mencuri $(23,9 \%)$, kasus narkoba $(17,8 \%)$, kasus asusila $(13,2 \%)$ dan kasus lainnya $(45,1 \%)$. Sistem database pemasyarakatan yang diperbaharui secara realtime di laman Direktorat Jenderal Pemasyarakatan Kementerian Hukum dan HAM RI menampilkan data jumlah anak yang dibina di LPKA dari tahun 2018-2020 sangat fluktuatif. Tahun 2018 jumlah yang dibina berjumlah 2.470 anak, tahun 2019 meningkat $7,81 \%$ menjadi 2.663 anak, namun mengalami penurunan sebanyak 16,37\% pada tahun 2020 (sampai dengan bulan Juli) menjadi 2.227 anak. Hal ini dikarenakan kebijakan dirumahkannya Anak karena Pandemi Covid-19. Jumlah anak yang berada di LPKA belum termasuk anak yang sedang ditahan di kantor polisi (Polsek, Polres, Polda, dan Mabes) karena kasusnya belum ditindaklanjuti. 
LPKA Kelas II Bandung, pada tahun 2019 membina sebanyak 109 ABH. Anak yang berada di LPKA kelas II Bandung, dituntut dapat beradaptasi dengan lingkungan lembaga, dimana sebelumnya mereka tinggal dilingkungan bebas dan tak terikat. Situasi ini membuat anak mengalami permasalahan ganda. Mereka harus menghadapi lingkungan baru yang sangat berbeda dengan lingkungan mereka sebelumnya. Anak merasa tidak nyaman dan mengalami kesulitan beradaptasi. Disisi lain, kalaupun mereka bebas, mereka ketakutan mengalami stigma dan diskriminasi dari keluarga, sanak saudara, tetangga, dan lingkungan masayarakat. Anak takut mengalami penolakan, pengasingan, dan pengucilan dari masyarakat.

Kondisi yang mengharuskan Anak dalam pembinaan di LPKA secara umum membuat mereka merasa bersalah dan menyesal atas perbuatan yang telah dilakukannya. Namun pada kenyataannya, justru Anak tidak mengalami penyesalan ataupun merasa bersalah sama sekali. Memiliki banyak teman sesama pelaku kejahatan mendorong anak menganggap kejahatan bukanlah pemasalahan yang besar. Kecenderungan lainnya yang terjadi Anak justru menyalahkan pihak atau situasi lain yang mengakibatkan mereka berhadapan dengan hukum. Kondisi anak yang merasa tidak bersalah dan cenderung menyalahkan situasi atau orang lain apabila dibiarkan maka akan menyebabkan munculnya rasa dendam. Anak menganggap dirinya benar atau positif dan menganggap bahwa dirinya tidak akan masuk ke dalam Lembaga Pembinaan seandainya orang, keadaan, atau situasi yang dianggap sebagai penyebab tidak ada atau tidak terjadi. Perasaan dendam pada diri anak akan mendorong anak mengulang kembali kejahatan yang dilakukannya.

Kecenderungan seseorang menilai dirinya secara positif dan menyalahkan orang lain atau situasi atas kegagalan yang dihadapinya menurut Robert A. Baron \& Donn
Byrne (2012) merupakan bagian dari kesalahan atribusi. Atribusi adalah proses mencari informasi bagaimana seseorang berbuat dan mengapa mereka berbuat demikian. Atribusi pada diri manusia seringkali keliru. Dua jenis kekeliruan atribusi disebut dengan efek faktor pengamat dan Self Serving Bias. Efek faktor pengamat adalah kecenderungan untuk mengatribusi perilaku positif pada faktor eksternal daripada faktor internal. Sedangkan Self Serving Bias mengatribusi perilaku positif pada faktor internal dan negatif pada faktor eksternal. Pendapat lain mengenai Self Serving Bias menurut Myers (2012) adalah tendensi untuk menganggap diri lebih baik dimana kecenderungan seseorang melayani (serve) dirinya, memenuhi keinginan diri, atau memandang sesuatu dalam diri secara positif. Bentuk dari Self Serving Bias yaitu Self Serving Attribution, Self Congratulatory Comparison, Illusory Optimism, dan False Consensus for Failings.

Self Serving Attribution adalah kecenderungan individu menempatkan keadaan positif karena dirinya sendiri dan hal negatif berasal dari luar dirinya. Individu juga seringkali menganggap dirinya lebih baik dari orang lain dalam berbagai hal yang disebut Self Congratulatory Comparison. Selain itu individu juga memiliki harapan masa depan yang terlalu optimis dan mengabaikan kemungkinan buruk yang disebut Illusory Optimism. False Consensus for Failings adalah anggapan kesalahan dan kegagalan yang dialaminya adalah hal yang wajar dan merasa setiap orang mengalami dan memiliki pandangan sama.

Anak dengan Self Serving Bias akan menyalahkan orang lain atas perbuatan yang dilakukannya sehingga sulit untuk mengintrospeksi diri. Perasaan tidak bersalah didorong oleh perasaan menganggap dirinya lebih baik jika dibandingkan dengan yang lain dalam berbagai hal. Self Serving Bias juga berbentuk optimisme yang berlebihan dan tidak realistis yang akan membawa anak ke dalam 
kondisi tidak perlu mengkhawatirkan, takut, waspada dan gentar terhadap yang akan dihadapi. Self Serving Bias juga menimbulkan perasaan bahwa dilingkungannya banyak orang yang memiliki kesamaan dengan dirinya. Perasaan tersebut didorong oleh bentuk kebiasaan dan perilaku buruk yang dimilikinya dianggap sebagai keunikan pribadi. Perilaku self serving bias pada dasarnya memang merupakan perilaku yang maladaptif. Namun terdapat pula perilaku self serving bias yang kemudian menjadi adaptif. Perilaku self serving bias adaptif ditunjukkan dengan tendensi untuk mencegah depresi, meningkatkan harga diri, dan menahan stres.

Hasil penjajagan awal yang dilakukan peneliti menunjukkan anak didik lembaga menjadikan kasus yang dihadapi bukanlah kesalahan mereka atau tidak sepenuhnya salah mereka. Keadaan ini memerlukan perhatian dan pembinaan untuk mengubah kognitif anak agar tidak menjadi residivis dikemudian hari. Selain itu, perubahan perilaku dan perbaikan dalam berbagai sisi diri anak adalah harapan adanya suatu pendisiplinan dalam suatu lembaga pembinaan anak berhadapan hukum.

Kedisiplinan dan perubahan diri tidak akan tercapai selama masih ada perilaku Self Serving Bias dalam diri anak. Dampak dari Self Serving Bias yang buruk apabila dibiarkan dapat mempengaruhi pola pikir dan pemahaman diri yang salah. Kemungkinan perkembangan masalah tidak hanya terbatas pada diri anak saja akan tetapi juga terhadap lingkungannnya. Sehingga sangat penting adanya suatu penelitian yang membahas tentang Self Serving Bias dalam diri anak yang berhadapan dengan hukum.

Self Serving Bias menurut Myers (2012) adalah tendensi untuk menganggap diri lebih baik atau memandang dirinya secara positif. Dalam artian segala hal yang bersifat positif yang terjadi dalam diri adalah berasal dari dalam internal diri sendiri. Sejalan dengan teori tersebut, Baron dan Donn Bryne (2004) menyatakan Self Serving Bias merupakan kecenderungan mengatribusi perilaku yang positif pada faktor-faktor internal dan mengatribusi perilaku yang negatif pada faktorfaktor eksternal. Berdasarkan pengertian tersebut dapat dikatakan bahwa self serving bias merupakan kecenderungan seseorang yang berfokus pada diri sendiri, yang berusaha untuk tampil baik dengan menghubungkan bahwa halhal yang baik berasal dari dalam diri sendiri, sedangkan peristiwa negatif terjadi karena faktor eksternal.

Self Serving Bias memiliki beberapa bentuk yang memiliki perbedaan satu sama lainnya. Bentuk-bentuk ini menjadi indikator dari adanya suatu Self Serving Bias pada seseorang. Setiap bentuk-bentuk ini memiiki karakteristik yang berbeda sesuai dengan wujud yang ditampakkan oleh orang yang melakuakn Self Serving Bias. Menurut Myers (2012) bentukbentuk dari self serving bias adalah:

$\begin{array}{lrr}\text { 1. Self-serving } & \text { attribution. } & \text { Adalah } \\ \text { kecenderungan } & \text { seseorang } & \text { yang }\end{array}$ menghubungkan hasil positif untuk diri sendiri dan hasil negatif pada suatu hal lain. Seseorang akan memandang dirinya sebagai pihak yang paling berperan ketika berhasil, dan menyalahkan orang lain ketika gagal.

2. Self Congratulatory Comparisons. Bentuk self serving bias dengan cara membandingkan diri sendiri lebih tinggi atau lebih baik dari orang lain merupakan kecenderungan seseorang yang memandang dirinya lebih etis, lebih memiliki kompetensi, pintar, baik, sedikit prasangka, lebih banyak mengerjakan sesuatu dari pada orang lain dan sedikit dalam membuat penilaian terhadap diri sendiri. Melalui perbandingan sosial (social comparisons), seseorang yang menilai dirinya lebih baik akan memiliki harga diri atau kepercayaan diri, tetapi juga dapat 
menimbulkan perasaan lebih superior dibandingkan dengan teman atau rekannya sehingga cenderung memiliki sikap sombong.

3. Illusory Optimism. Optimisme yang tidak realistis merupakan suatu keyakinan yang tidak realistis. Baron \& Donn Byrne (2004) menyebutnya sebagai bias optimisme (optimistic bias) yaitu suatu predisposisi untuk mengharapkan agar segala sesuatu dapat berakhir dengan baik. Kecenderungan ini dapat dilihat dalam berbagai konteks yang berbeda yaitu kebanyakan orang percaya bahwa mereka memiliki kemungkinan yang lebih besar dari orang lain untuk mendapatkan pekerjaan yang baik, memiliki pernikahan yang baik, dan hidup hingga usia tua, namun kemungkinan lebih kecil akan mengalami peristiwa negatif. Bentuk ini juga terlihat pada kecenderungan menunda pekerjaan karena yakin akan dapat menyelesaikan pekerjaannya dalam waktu yang singkat. Akan tetapi kenyataannya, membutuhkan waktu yang lebih lama untuk menuntaskannya

4. False Consensus for Failings. Myers (2012) menyatakan bahwa konsensus yang salah yaitu kecenderungan seseorang untuk menganggap orang lain memiliki sikap, pandangan, atau minat yang sama dengan dirinya sendiri. Konsensus yang salah juga dapat terjadi ketika seseorang cenderung menganggap orang lain juga memiliki sifat buruk atau hal-hal buruk lainnya yang sama dengan dirinya. Sedangkan keunikan yang salah merupakan kecenderungan seseorang yang menganggap bahwa kelebihan yang dimilikinya merupakan sesuatu yang unik. Kesalahan konsensus ini bisa terjadi karena menggeneralisasikan dari sebuah sampel yang terbatas yang dengan mencolok mencakup diri kita. Sampel yang terbatas didapatkan dari pengetahuan dan wawasan diri individu terhadap dirinya dan lingkungan kecilnya. Karena kekurangan informasi lain tersebut individu akan mulai berfikir untuk dirinya memasukkan pengetahuan yang dirinya miliki kepada orang lain dan menggunakan respon diri sendiri sebagai sebuah petunjuk bagi kemungkinan respon mereka (Dawes dalam Myers, 2012).

Keterlibatan pekerja sosial dalam menangani Anak Berhadapan dengan Hukum (ABH) merupakan bidang praktik pekerjaan sosial koreksional. Pekerjaaan sosial merupakan suatu profesi yang bertujuan untuk memperbaiki dan meringankan kemampuan berfungsi sosial serta menciptakan kondisi-kondisi yang memungkinkan orang dapat mencapai tujuan hidupnya. Pekerja sosial dipekerjakan dalam lingkungan peradilan pidana dengan peran utama memberikan layanan langsung dan tidak langsung kepada klien. Pekerja sosial menyediakan layanan klinis atau langsung bagi korban kejahatan dan pelanggar pidana baik sebagai pelaku, korban maupun saksi. Pekerja sosial membantu pelaku mengubah pola perilaku sehingga pelaku dapat berhubungan secara konstruktif dengan orang lain dan menjadi dapat diterima secara sosial. Fokus pekerja sosial adalah pada proses perbaikan yang ada dalam diri individu sebagai seseorang yang telah melakukan pelanggaran hukum. Ini dilakukan melalui dua jalan yaitu 1) Bekerja dengan individu untuk membantunya berubah melalui pemahaman diri yang lebih baik dan dengan memanfaatkan kekuatan dan sumber daya orang itu sendiri, dan 2) modifikasi lingkungan untuk menghasilkan iklim sosial yang lebih sehat dalam tempat tinggal. Keberadaan pekerja sosial telah diakui peranannya dalam penanganan Anak Berhadapan Hukum yang tertuang dalam UU No 11 tahun 2012 tentang Sistem Peradilan Anak (Susilowati. E, 2017; 2018)

Prinsip utama pekerja sosial ketika bekerja dengan pelaku kejahatan dan keluarga mereka adalah membantu klien untuk bisa membantu diri mereka sendiri; tidak mengutuk atau bermoral, menerima klien sebagaimana adanya, dan juga perilaku mereka, terlepas dari apa yang telah 
terjadi di masa lalu; menghormati hak penentuan nasib diri mereka bahwa mereka juga bisa membantu dirinya dan merasakan melalui kesulitan dan situasi mereka, tetapi tidak untuk membuat keputusan dasar bagi mereka, membantu untuk memberikan iklim emosional di mana mereka dapat menghadapi masalah, kewajiban, dan mencari solusi yang tepat; mempelajari dan memahami perilaku normal sebagai perilaku antisosial untuk memahami mengapa kenakalan dan kejahatan terjadi dan apa yang harus dilakukan terhadap mereka; memberikan rasa keamanan bukan hukuman fisik; dan menggunakan otoritas secara positif untuk membantu diri mereka sendiri menghadapi masalah mereka dan menyesuaikan pemikiran dan perilaku.

Fungsi utama Pekerja Sosial dalam kaitannya dalam kenakalan remaja dan kejahatan adalah membantu memperkuat motivasi, memungkinkan untuk ventilasi perasaan, pemberian informasi, menentukan situasi, memodifikasi lingkungan, membantu individu dalam membantu mengatur kembali pola perilaku, dan memfasilitasi Rujukan

Berdasarkan latar belakang permasalahan diatas menunjukkan sebuah fenomena yang menarik untuk melakukan penelitian tentang perilaku Self Serving Bias oleh anak yang berhadapan dengan hukum di Lembaga Pembinaan Khusus Anak Kelas II Bandung. Secara khusus penelitian ini bertujuan untuk mengetahui karakteristik informan; Self Serving Attribution informan; Self Congratulatory Comparison informan; Illusory Optimism informan; False Consensus for Failings informan; dan Harapan Anak Berhadapan dengan Hukum di Lembaga Pembinaan Khusus Anak Kelas II Bandung.

\section{METODE}

Metode penelitian yang digunakan dalam penelitian ini adalah penelitian kualitatif dengan desain studi kasus. Penelitian Kualitatif menurut Moleong (2011) yaitu penelitian yang menghasilkan prosedur analisis yang tidak menggunakan prosedur analisis statistik atau cara kuantifikasi lainnya.

Penelitian ini menggunakan pendekatan kualitatif karena peneliti menganggap permasalahan yang diteliti tentang self serving bias pada $\mathrm{ABH}$ cukup kompleks dan dinamis, sehingga dengan pendekatan kualitatif sangat dimungkinkan peneliti dapat mendalami dan mendapatkan data yang lengkap dan utuh terkait dengan Self Serving Bias pada setiap ABH yang menjadi informan penelitian. Selain itu, penulis juga bermaksud untuk memahami situasi sosial yang dihadapi anak yang berhadapan dengan hukum dan berupaya untuk menemukan pola, hipotesis, dan teori yang sesuai dengan data yang diperoleh di lapangan. Metode studi kasus dipilih karena anak yang berhadapan dengan hukum memiliki kasus dan karakteristik yang berbeda dalam melakukan self serving bias dengan gejala maladaptif.

Teknik penentuan informan dilakukan yaitu purposive, dimana penentuan sumber data berdasarkan kriteria yang ditetapkan sesuai dengan ketersediaan data di lapangan. Peneliti menentukan informan ABH dengan beberapa kriteria/pertimbangan sebagai berikut:

1. Berusia 16 - 18 tahun.

2. Jenis kelamin laki-laki.

3. Sudah mendapatkan vonis hukuman dari pengadilan hingga minimal dua tahun (Anak Pidana) dan anak yang menjalani hukuman sampai umur 18 tahun di Lembaga Pembinaan Khusus Anak Kelas II Bandung

4. Pendidikan terakhir atau sedang menempuh pendidikan SD, SMP dan SMA.

5. Petugas Lembaga Pemasyarakatan yang menjadi wali atau bertugas sebagai guru di SD, SMP dan SMA di Lembaga Pembinaan Khusus Anak Kelas II Bandung.

Berdasarkan kriteria diatas, diambil lima informan Anak Berhadapan Hukum sebagai informan utama, dan empat informan pendukung dari petugas/pendamping dan teman informan utama yang ditentukan Peneliti ketika berada 
dilapangan disesuaikan dengan kebutuhan data pendukung yang diperoleh dari informan utama. Penentuan ini didasarkan bahwa dalam penelitian kualitatif tidak dilihat pada jumlah informan tetapi lebih pada kelengkapan dan kedalaman data informasi yang diperoleh sehingga mencapai titik jenuh melalui wawancara mendalam (Indepth Interview).

\section{HASIL PENELITIAN}

Hasil penelitian memuat tentang karakteristik informan, Self Serving Attribution,
Self Congratulatory Comparison, Illusory Optimism, False Consensus for Failings dan Harapan Informan. Berikut merupakan penjelasan dari hasil penelitian yang telah dilakukan oleh peneliti

\section{Karakteristik Informan}

Penelitian ini menentukan lima informan Anak Berhadapan Hukum sebagai informan utama dan empat informan pendukung dari petugas/pendamping dan teman informan utama.

Tabel 1: Karakteristik Informan Penelitian

\begin{tabular}{|c|c|l|c|l|}
\hline Nama & Umur & Agama & Pendidikan & \multicolumn{1}{c|}{ Kasus } \\
\hline EP & 17 & Islam & SD (tidak lulus) & Pengedaran Narkoba \\
\hline MC & 18 & Khatolik & STM/SMK & Pengedaran Narkoba \\
\hline TG & 17 & Islam & SMP & Pembunuhan \\
\hline RF & 17 & Islam & SMA & Perlindungan Anak \\
\hline DD & 17 & Islam & SMA & Pembunuhan \\
\hline
\end{tabular}

Sumber : Hasil Penelitian 2020

Tabel 1 menunjukkan bahwa latar belakang kasus terdapat dua anak pengedar narkotika, dua anak terjerat kasus pembunuhan dan satu anak terjerat kasus perlindungan anak.

\section{Self Serving Attribution}

Proses mencari sebuah penyebab dari keberhasilan dan kegagalan yang dialami oleh diri sendiri seringkali mengalami kesalahan. Self serving attribution merupakan suatu bentuk kecenderungan yang menghubungkan keberhasilan atau hal-hal positif dengan diri sendiri dan menghubungkan kegagalan yang dialami atau hal-hal negatif pada faktor eksternal. Berkaitan dengan hal tersebut, setiap orang memiliki pandangan yang berbeda atau tolak ukur dalam menyatakan keberhasilan dan kegagalan yang dialaminya. Hasil penelitian menunjukkan bahwa kelima informan melakukan perilaku Self Serving Attribution sebagai berikut:

Informan EP menyatakan bahwa keberhasilan merupakan suatu pencapaian dari target yang ditetapkan dan kegagalan adalah sebaliknya. Informan EP menuturkan "Kalau menurut saya mah keberhasilan itu kalo kita punya keinginan atau target dan kita dapat memenuhi atau mencapainya dengan usaha keras.....Nah kalo kegagalan ya berarti sebaliknya kalo kita punya keinginan dan nggak tercapai kak". Keberhasilan yang sudah diraih oleh EP adalah mendapatkan uang dari bekerja, membeli motor yang diinginkan, dan mengalami peningkatan dalam hal keagamaan selama berada di LPKA. Seluruh keberhasilan tersebut disampaikan oleh EP merupakan hasil kerja kerasnya sendiri dan kemauan hatinya. EP tidak menunjukkan kontribusi eksternal terhadap keberhasilan yang diraihnya. Sedangkan kegagalan yang dialami oleh EP adalah putus sekolah, terlibat dalam pengedaran narkoba, dan masuk kedalam LPKA. Berkenaan dengan kegagalan EP menyatakan hal tersebut karena faktor-faktor diluar dirinya yaitu orangtuanya yang tidak menyekolahkan dan ajakan temannya untuk masuk kedalam dunia narkoba. 
Informan MC memaknai keberhasilan dan kegagalan sebagai hasil akhir yang baik atau berhasil dan kegagalan adalah sebaliknya. Hal tersebut disampaikan MC sebagai berikut: "...Keberhasilan itu apabila kita melakukan sesuatu yang berakhir baik atau berhasil....kalau kegagalan ya sebaliknya". Pengalaman MC dalam meraih keberhasilan adalah dapat membeli gawai dan pakaian serta mendapat uang dan pekerjaan. MC menyatakan seluruh keberhasilannya adalah usaha keras dan kerjanya selama ini. Sedangkan kegagalan yang dialami adalah putus sekolah SMK dan terjerumus kedalam narkoba dan masuk kedalam LPKA. Perihal kegagalan MC mengatakan akibat pengaruh dari teman-teman dan lingkungan yang memberikan efek buruk.

Keberhasilan menurut TG adalah: “........sesuatu yang dapat dilakukan dan kegagalan adalah sesuatu yang tidak bisa dilakukan". TG memaknai keberhasilan dan kegagalan berdasarkan dapat atau tidaknya suatu hal dilakukan. Keberhasilan yang diraih TG adalah membuat kerajinan tangan aksesoris dan terampil bongkar pasang motor. Keberhasilan yang diraih TG didapatkannya melalui ketekunan berlatih dan kemampuan daya ingat. Kegagalan yang dialami TG adalah putus sekolah SMP dan masuk kedalam LPKA. Kegagalan yang dialami akibat orangtuanya tidak mampu dan pengaruh teman.

RF menyampaikan bahwa keberhasilan dan kegagalan adalah: “... sesuatu hal yang bisa dilakukan dan dipertahankan. Sedangkan kegagalan adalah hal yang tidak bisa dipertahankan dan dilakukan". RF memaknai keberhasilan dan kegagalan dari bertahan atau tidaknya suatu hal saat dilakukan. Keberhasilan $\mathrm{RF}$ adalah mendapatkan penghasilan atau uang dan membantu teman. Menurut RF keberhasilan tersebut hasil dari kemauan yang kuat dan usaha kerasnya. Sedangkan kegagalan yang dialami RF adalah ditangkap Satpol PP, pelanggaran tata tertib LPKA, dan terlibat dalam kasus hukum hingga masuk LPKA. Penyebab kegagalan yang dialami adalah karena pengaruh buruk adik, teman, dan lingkungannya.

Makna dari keberhasilan dan kegagalan menurut DD adalah: “...tercapainya suatu target yang diinginkan. Sedangkan kegagalan adalah apabila hal tersebut tidak tercapai”. DD memaknai keberhasilan sebagai pencapaian target dan kegagalan adalah sebaliknya. Keberhasilan DD adalah juara kelas, mampu bongkar pasang motor, dan tim sepakbolanya menang. DD mengatakan seluruh keberhasilan tersebut adalah karena usaha, ketekunan, kreatifitas, dan kecerdasan dirinya sendiri. Bahkan dalam tim sepakbola DD mengatakan berkat dirinya tim dapat meraih kemenangan. Kegagalan yang dialami adalah gagal masuk Sekolah Sepak Bola (SSB), melakukan pelanggaran di LPKA, dan terlibat kasus hukum sehingga masuk ke LPKA. Kegagalan masuk SSB karena orangtua tidak mau membiayai. Sedangkan kegagalan pelanggaran dan terlibat kasus hukum karena terseret dan dipengaruhi temannya.

Keberhasilan dan kegagalan kelima informan tersebut diatas, didukung oleh hasil hasil observasi yang dilakukan peneliti melalui permainan dengan informan. Hasil permainan menunjukkan kelima informan mengatribusi-kan keberhasilan dengan diri sendiri dan menyalahkan situasi atau orang lain atas kegagalan atau peristiwa negatif yang mereka alami. Hasil observasi melalui media permainan menunjukkan bahwa seluruh anak mengakui bagian besar dalam suatu keberhasilan dalam permainan sehingga menang dan menunjuk faktor eksternal diri ketika gagal atau mengalami kekalahan. 
Tabel 2 Self Serving Attribution Informan

\begin{tabular}{|c|c|c|c|c|c|}
\hline No & Informan & Keberhasilan & $\begin{array}{c}\text { Faktor } \\
\text { Keberhasilan }\end{array}$ & Kegagalan & $\begin{array}{l}\text { Penyebab } \\
\text { Kegagalan }\end{array}$ \\
\hline \multirow[t]{3}{*}{1.} & \multirow[t]{3}{*}{ EP } & Menghasilkan Uang & $\begin{array}{l}\text { Usaha dan kerja } \\
\text { keras }\end{array}$ & Putus Sekolah & $\begin{array}{l}\text { Orangtua tidak } \\
\text { mampu dan tidak } \\
\text { mendukung }\end{array}$ \\
\hline & & Membeli Motor & $\begin{array}{l}\text { Strategi EP uang } \\
\text { cepat terkumpul }\end{array}$ & $\begin{array}{l}\text { Terjerumus dalam } \\
\text { narkba }\end{array}$ & $\begin{array}{l}\text { Karena ajakan } \\
\text { teman TB }\end{array}$ \\
\hline & & Peningkatan agama & Kemauan sendiri & $\begin{array}{l}\text { Terlibat kasus } \\
\text { hukum }\end{array}$ & $\begin{array}{l}\text { TB mengajak jadi } \\
\text { pengedar }\end{array}$ \\
\hline \multirow[t]{2}{*}{2.} & \multirow[t]{2}{*}{$\mathrm{MC}$} & $\begin{array}{l}\text { Membeli barang } \\
\text { yang diinginkan }\end{array}$ & $\begin{array}{l}\text { Usaha dan kerja } \\
\text { keras diri sendiri }\end{array}$ & $\begin{array}{ll}\begin{array}{l}\text { Putus } \\
\text { (STM) }\end{array} & \text { Sekolah } \\
\end{array}$ & $\begin{array}{l}\text { Karena pengaruh } \\
\text { teman disekolah }\end{array}$ \\
\hline & & $\begin{array}{l}\text { Mendapatkan } \\
\text { pekerjaan \& uang }\end{array}$ & $\begin{array}{l}\text { Usaha dan kerja } \\
\text { keras diri sendiri }\end{array}$ & $\begin{array}{l}\text { Terjerumus } \\
\text { narkoba dan } \\
\text { masuk LPKA }\end{array}$ & $\begin{array}{l}\text { Karena teman dan } \\
\text { lingkungan yang } \\
\text { tidak baik }\end{array}$ \\
\hline \multirow[t]{2}{*}{3.} & \multirow[t]{2}{*}{ TG } & Membuat aksesoris & $\begin{array}{l}\text { Berlatih sendiri } \\
\text { dan tekun }\end{array}$ & $\begin{array}{l}\text { Putus sekolah } \\
\text { (SMP) }\end{array}$ & $\begin{array}{l}\text { Karena orangtua } \\
\text { tidak mampu }\end{array}$ \\
\hline & & $\begin{array}{l}\text { Bongkar pasang } \\
\text { mesin motor }\end{array}$ & $\begin{array}{l}\text { mengulik dan } \\
\text { mengingat sendiri }\end{array}$ & Masuk ke LPKA & $\begin{array}{l}\text { Karena teman yang } \\
\text { mengajak }\end{array}$ \\
\hline \multirow[t]{4}{*}{4} & \multirow[t]{4}{*}{$\mathrm{RF}$} & $\begin{array}{l}\text { Mendapat uang dari } \\
\text { merongsok }\end{array}$ & $\begin{array}{l}\text { usaha dan kerja } \\
\text { keras sendiri }\end{array}$ & Diciduk satpol PP & Karena adik lelet \\
\hline & & $\begin{array}{l}\text { Membantu teman } \\
\text { saat membutuhkan }\end{array}$ & $\begin{array}{l}\text { Kemauan hati \& } \\
\text { kesadaran diri }\end{array}$ & $\begin{array}{l}\text { Pelanggaran tata } \\
\text { tertib LPKA }\end{array}$ & $\begin{array}{l}\text { Anak lain dan } \\
\text { petugas }\end{array}$ \\
\hline & & & & $\begin{array}{l}\text { Terlibat kasus } \\
\text { hukum }\end{array}$ & $\begin{array}{l}\text { Korban yang harus } \\
\text { melapor }\end{array}$ \\
\hline & & & & $\begin{array}{l}\text { Tidak dapat } \\
\text { remisi }\end{array}$ & $\begin{array}{l}\text { Kakak tidak niat } \\
\text { mengurus }\end{array}$ \\
\hline \multirow[t]{4}{*}{4.} & $\mathrm{RF}$ & $\begin{array}{l}\text { Mendapat uang dari } \\
\text { merongsok }\end{array}$ & $\begin{array}{l}\text { usaha dan kerja } \\
\text { keras sendiri }\end{array}$ & Diciduk satpol PP & Karena adik lelet \\
\hline & & $\begin{array}{l}\text { Membantu teman } \\
\text { saat membutuhkan }\end{array}$ & $\begin{array}{l}\text { Kemauan hati \& } \\
\text { kesadaran diri }\end{array}$ & $\begin{array}{l}\text { Pelanggaran tata } \\
\text { tertib LPKA }\end{array}$ & $\begin{array}{l}\text { Anak lain dan } \\
\text { petugas }\end{array}$ \\
\hline & & & & $\begin{array}{l}\text { Terlibat kasus } \\
\text { hukum }\end{array}$ & $\begin{array}{l}\text { Korban yang harus } \\
\text { melapor }\end{array}$ \\
\hline & & & & Tidak dapat remisi & $\begin{array}{l}\text { Kakak tidak niat } \\
\text { mengurus }\end{array}$ \\
\hline \multirow[t]{2}{*}{5.} & DD & bidang akademik & $\begin{array}{l}\text { Karena } \\
\text { kecerdasan diri }\end{array}$ & Gagal masuk SSB & $\begin{array}{l}\text { Orangtua egois dan } \\
\text { tidak mendukung }\end{array}$ \\
\hline & & $\begin{array}{l}\text { Bongkar Pasang } \\
\text { Motor }\end{array}$ & $\begin{array}{l}\text { Kreatifitas diri } \\
\text { dan rajin }\end{array}$ & $\begin{array}{l}\text { Pelanggaran Tatib } \\
\text { LPKA }\end{array}$ & $\begin{array}{l}\text { Di "embet" dan anak } \\
\text { lain mencari masalah }\end{array}$ \\
\hline
\end{tabular}

Sumber : Hasil Penelitian Mahasiswa 2020

Self Congratulatory Comparison

Setiap individu memiliki pemikiran dalam dirinya bahwa setidaknya dia berada direntang pertengahan atas penilaian akan sesuatu. Hal tersebut muncul pada saat diri kita mengukur berbagai hal dalam diri.
Kecenderungan tersebut disebut self congratulatory comparison. Perbandingan diri yang menyatakan bahwa diri sendiri lebih etis, lebih berwibawa, lebih cerdas, lebih berkompeten dan sebagainya dibanding orang 
lain. Hal ini menjadi tidak wajar ketika perbandingan tersebut menjadi bias dan tidak perbandingan tersebut menjadi bias dan tidak sesuai dengan ukuran yang seharusnya. Sehingga ketidaksesuaian tersebut mendorong individu untuk selalu memposisikan dirinya berada didalam sudut postitif terhadap setiap aspek.

Self congratulatory comparison pada $\mathrm{ABH}$ di LPKA Kelas II Bandung dapat dilihat dari beberapa aspek. Aspek-aspek tersebut adalah etika, intelegensi, ketertiban, aktivitas ibadah, kasus yang di hadapi, dan putusan hukuman.

Informan EP menyatakan bahwa dirinya merasa memiliki sopan santun dan etika yang lebih baik dibanding anak didik yang lain walaupun juga ada kalanya EP merasa dirinya kadang tidak sopan akan tetapi dibanding dengan anak didik yang lain merasa memiliki etika berbicara dan berperilaku yang baik. EP menyatakan bahwa dalam berkomunikasi jarang bahkan tidak pernah berkata kasar. EP mengatakan kalau seandainya dirinya mendapat kesempatan untuk bersekolah pasti bisa dan lebih pandai jika dibandingkan dengan anak-anak di LPKA yang rata-rata mengalami putus sekolah. EP mengaku saat ini kurang dalam hal intelegensi akan tetapi apabila diberi kesempatan sekolah pasti bisa. Perihal ketertiban EP menyatakan bahwa dirinya menjadi semakin tertib dalam melakukan segala sesuatu sehingga pola hidupnya menjadi teratur. EP selalu mengupayakan sholat lima waktu meskipun tidak langsung dilaksanakan setelah Adzan berbunyi. EP merasa praktik ibadahnya lebih baik jika dibandingkan dengan teman-temannya.

EP melihat bahwa kasus yang dialaminya sebagai cara untuk merubah perilaku atau memberikan kesadaran untuk berubah. EP menganggap hal tersebut sebagai ujian yang harus dijalani meskipun banyak anak berpendapat bahwa kasus pidana narkoba yang dilakukannya termasuk kasus tindak pidana berat karena masa hukuman yang lebih lama. EP yang menghadapi kasus narkoba dijatuhi hukuman lima tahun dua bulan. Akan tetapi sama halnya dengan MC yang menghadapi kasus yang sama, walaupun hukumannya masih dibawah MC akan tetapi EP merasa hukuman yang diterimanya terlalu tinggi dan tidak adil.

MC merasa etikanya menjadi lebih baik, tapi jika dibanding dengan anak didik lain MC biasa saja. MC mengaku seringkali berkata kasar dan kurang sopan kepada pendamping. Tetapi MC mengatakan masih wajar karena ada banyak yang lebih parah. MC mengatakan cukup bersemangat untuk bersekolah, merasa yakin dirinya memiliki tingkat intelegensi yang lebih tinggi dibanding anak-anak yang lain. Disekolahnya MC temasuk berprestasi yaitu masuk tujuh besar terbaik dikelasnya.

MC menyatakan dirinya cukup tertib dibanding yang lain. Setiap kegiatan selalu rajin datang dan tidak pernah membolos. MC rajin mengikuti apel pagi dan sering mengajak anak lain untuk segera berkumpul. Pernyataan MC dibenarkan oleh informan $\mathrm{KH}$ menyatakan bahwa MC memang rajin dan tidak pernah bolos kegiatan. Selain itu juga MC selalu taat aturan dan tidak pernah melanggar peraturan LPKA.

Aktifitas ibadah MC sebagai umat Katolik, yaitu ibadah setiap hari jumat, jarang dilaksanakan. MC merasa kasusnya tidak memalukan dan lebih baik dibanding anak lain. Hal ini menunjukkan MC memiliki pemahaman bahwa dibandingkan dengan kasus lainnya pelanggaran hukumnya tergolong lebih ringan. MC merasa lebih dirugikan karena hukuman paling tinggi. Namun MC berusaha untuk mempertahankan harga dirinya (self esteem) walaupun lebih lama dan tidak terima. Untuk mempertahankan harga diri MC melihat sisi positif yaitu masih bisa bertemu orangtua.

Informan TG adalah anak pendiam. Hal tersebut berpengaruh terhadap cara berbicara dan perilakunya. TG cenderung tidak meladeni ucapan-ucapan kasar dari teman-temannya dan memilih diam. TG menilai dirinya sudah baik 
dalam etika tetapi memiliki intelegensi yang kurang karena putus sekolah. Seandainya dapat melanjutkan pendidikan, TG mengaku pasti bisa bersaing dengan yang lain. TG menilai termasuk yang paling tertib karena belum pernah melakukan pelanggaran. TG juga menyatakan tidak pernah punya masalah dengan anak didik yang lain sehingga tidak pernah mendapat teguran.

Informan TG mengakui kadang-kadang tidak melaksanakan sholat. Tetapi jika dibandingkan dengan yang lain, masih banyak anak didik lainnya yang tidak melaksanakan sholat. Kasus pembunuhan yang dilakukannya dinilai masih standar di banding pembunuhan berencana. Informan menilai kasusnya biasa saja jika dibandingkan dengan tindak pidana anak didik lainnya. Informan TG menyatakan tindak pidana yang paling berat adalah pembunuhan berencana dibandingkan dengan kasus tindak pidana yang dilakukannya yaitu pengeroyokan meskipun akibat dari pengeroyokan tersebut menimbulkan korban jiwa.

Informan RF menyatakan dirinya kurang sopan dan tidak menjaga etika, tetapi merasa wajar dibanding anak didik yang lain. RF menyatakan dirinya masih jauh lebih baik dari yang lain. Banyak Anak yang bertindak lebih dari dirinya dalam hal ketidaksesuaian dengan etika yang berlaku. RF merasa intelegensinya kurang tetapi masih dapat bersaing jika dibandingkan anak didik di LPKA.

Dalam hal ketertiban RF menyatakan dirinya beberapa kali melanggar peraturan di LPKA tetapi merasa masih banyak anak lainnya yang melanggar. Sehingga dirinya merasa masih lebih baik dibanding Anak yang lain. RF selalu mengupayakan sholat lima waktu meskipun selalu telat. Baginya yang penting melaksanakan ibadah. RF melakukan tindakan asusila terhadap sesama anak dibawah umur. RF merasa pelanggaran hukum yang dilakukan standar dan sama saja dengan anak didik lain.
RF merasa dirinya tidak melakukan pelanggaran yang lebih berat dibanding Anak yang lain. RF menilai hukuman yang dijalaninya selama 4 tahun lebih lama dibandingkan dengan yang lain. Menurutnya ini tidak adil dan ada kemungkinan kecurangan dalam penentuan masa hukuman dalam proses persidangan.

Etika pada Informan DD seringkali tidak sopan namun merasa masih lebih baik dibandingkan Anak lainnya. DD merasa lebih pintar dibandingkan anak didik lain karena memiliki kecerdasan tinggi. Hal ini dikatakan bahwa dirinya memiliki kemampuan memahami sesuatu hanya dengan belajar biasa tanpa harus belajar dengan tekun. DD pernah dihukum akan tetapi merasa lebih baik dibandingkan anak didik lain. Dirinya dihukum bukan karena kesalahannya akan tetapi karena Anak lain yang mencari masalah. DD merasa dirinya lebih tertib jika dibandingkan dengan anak yang lainnya. DD merasa rajin sholat walaupun tidak lengkap lima waktu dan merasa anak didik lain tidak lebih baik dari dirinya.

Berkenaan dengan kasus atau pelanggaran hukum yang dilakukan, DD merasa kasusnya lebih berat dibanding anak didik lain. DD mengatakan bahwa kasus pembunuhannya memang berat jika dibandingkan dengan anak yang lainnya. Namun dirinya merasa hukumannya tidak adil masih terlalu tinggi walapun dirinya sudah melakukan pembelaan. Meskipun hukumannya jika dibanding anak lain termasuk hukuman yang ringan.

Semua informan merasa dirinya lebih baik dalam hal etika didalam LPKA. Sebagian besar Informan memiliki kepercayaan diri lebih baik dalam hal intelegensi dibandingkan dengan anak didik di LPKA yang lain. Selain itu beberapa Informan menyatakan apabila mendapatkan pendidikan yang layak maka dirinya akan semakin berkembang. Hanya dua Informan yang menyatakan dirinya berada di rata-rata anak didik yang lain. Perihal ketertiban didalam LPKA setiap Informan menyatakan mereka masih lebih tertib. Walaupun ada yang 
pernah melanggar peraturan tapi hal tersebut masih wajar dan masih lebih ringan dibanding pelanggaran anak didik yang lain. Dalam hal ibadah beberapa menyatakan lebih baik dan lebih rajin dibanding anak lain. Namun juga terdapat anak yang menyatakan dengan anak yang lain sama saja atau rata-rata.

Kasus yang dihadapi informan berbeda. Membandingkan kasusnya dengan anak yang lain semua menyatakan bahwa kasusnya lebih ringan dan terdapat kasus yang lebih berat dibanding kasus yang dihadapi mereka saat ini. Informan menyatakan sebagian besar menerima hukuman yang terlalu tinggi untuk kasusnya. Ada sudah mendapatkan hukuman lebih rendah dibanding kasus yang sama namun tetap menyatakan hukumannya terlalu tinggi. Namun ada juga yang merasa perbedaan hukuman yang cukup tinggi jauh lebih kecil.

Tabel 3 Self Congratulatory Comparison Informan

\begin{tabular}{|c|c|c|c|c|c|c|}
\hline No & Perihal & EP & MC & TG & RF & DD \\
\hline 1. & Etika & $\begin{array}{l}\text { lebih baik dengan } \\
\text { anak didik lain }\end{array}$ & $\begin{array}{l}\text { lebih baik } \\
\text { dengan anak } \\
\text { didik lain }\end{array}$ & $\begin{array}{l}\text { lebih baik } \\
\text { dengan anak } \\
\text { didik lain }\end{array}$ & $\begin{array}{l}\text { lebih baik } \\
\text { dengan anak } \\
\text { didik lain }\end{array}$ & $\begin{array}{l}\text { lebih baik } \\
\text { dengan anak } \\
\text { didik lain }\end{array}$ \\
\hline 2. & Intelegensi & $\begin{array}{l}\text { rata-rata namun } \\
\text { disekolah merasa } \\
\text { lebih baik dari } \\
\text { anak yang lain. }\end{array}$ & $\begin{array}{l}\text { Merasa lebih } \\
\text { baik dari anak } \\
\text { didik yang lain. }\end{array}$ & $\begin{array}{l}\text { rata-rata namun } \\
\text { disekolah } \\
\text { merasa lebih } \\
\text { baik dari anak } \\
\text { lain }\end{array}$ & $\begin{array}{l}\text { rata-rata } \\
\text { karena tidak } \\
\text { terlalu suka } \\
\text { belajar. }\end{array}$ & $\begin{array}{l}\text { lebih cerdas } \\
\text { dibanding } \\
\text { anak didik } \\
\text { yang lain. }\end{array}$ \\
\hline 3. & Ketertiban & $\begin{array}{l}\text { Merasa lebih } \\
\text { tertib }\end{array}$ & $\begin{array}{l}\text { Merasa lebih } \\
\text { tertib }\end{array}$ & $\begin{array}{l}\text { Merasa lebih } \\
\text { tertib }\end{array}$ & Merasa tertib & $\begin{array}{l}\text { Merasa lebih } \\
\text { tertib }\end{array}$ \\
\hline 4. & Ibadah & $\begin{array}{l}\text { Merasa Lebih } \\
\text { Rajin Beribadah }\end{array}$ & $\begin{array}{l}\text { Merasa Rata- } \\
\text { Rata }\end{array}$ & $\begin{array}{l}\text { Merasa Lebih } \\
\text { Rajin } \\
\text { Beribadah } \\
\end{array}$ & $\begin{array}{l}\text { Merasa Lebih } \\
\text { Rajin } \\
\text { Beribadah }\end{array}$ & $\begin{array}{l}\text { Merasa Lebih } \\
\text { Rajin } \\
\text { Beribadah } \\
\end{array}$ \\
\hline 5 . & Kasus & $\begin{array}{l}\text { Merasa Lebih } \\
\text { Ringan }\end{array}$ & $\begin{array}{l}\text { Merasa Lebih } \\
\text { Ringan }\end{array}$ & $\begin{array}{l}\text { Merasa Lebih } \\
\text { Ringan }\end{array}$ & $\begin{array}{l}\text { Merasa Lebih } \\
\text { Ringan }\end{array}$ & $\begin{array}{l}\text { Merasa } \\
\text { Lebih } \\
\text { Ringan } \\
\end{array}$ \\
\hline 6. & $\begin{array}{l}\text { Lama } \\
\text { hukuman }\end{array}$ & $\begin{array}{l}\text { Merasa Lebih } \\
\text { Tinggi/dirugikan }\end{array}$ & $\begin{array}{l}\text { Merasa Lebih } \\
\text { Tinggi/dirugi- } \\
\text { kan }\end{array}$ & $\begin{array}{l}\text { Merasa Lebih } \\
\text { Tinggi/diru- } \\
\text { gikan }\end{array}$ & $\begin{array}{l}\text { Merasa Lebih } \\
\text { Tinggi/diru- } \\
\text { gikan }\end{array}$ & $\begin{array}{l}\text { cukup adil } \\
\text { setelah } \\
\text { pembelaan }\end{array}$ \\
\hline
\end{tabular}

Sumber : Hasil Penelitian 2020

\section{Illusory Optimism}

Sebagian besar orang menunjukkan optimisme yang tidak realistis pada lingkungannya. Setiap orangtua akan lebih mengharapkan anaknya bersekolah ditempat yang bagus, lulus dengan nilai terbaik, tetap sehat, dan selalu bahagia. Kebanyakan orang mengesampingkan adanya kemungkinan anak tersebut depresi, terkena sakit, dropout dari kampus, dan kemungkinan lainnya. Anak berhadapan hukum $(\mathrm{ABH})$ sangat rawan terhadap perilaku illusory Optimism dikarenakan mereka lebih banyak memandang kemungkinan mengalami hal positif dibanding hal-hal negatif.

EP memiliki optimisme setelah keluar dari LPKA dapat membuka usahanya sendiri dalam bidang mekanik. EP ingin setelah keluar akan membuka bengkel. Untuk mencapai itu EP mencari uang terlebih dahulu dengan bekerja. EP juga meyakini akan mendapatkan uang dan pekerjaan setelah keluar. EP sangat percaya dapat segera mendapatkan uang dan pekerjaan setelah keluar dari LPKA.. 
Informan MC memiliki optimisme yang tidak realistis, yaitu bayangan optimisme dalam bentuk memiliki kesabaran dalam menjalani kehidupan di dalam LPKA dan optimisme setelah keluar dari LPKA. Illusory optimism berupa keyakinan akan mengalami hal baik selama di LPKA yaitu memiliki kesabaran, mampu mengikuti aturan, dan dapat lebih rajin ibadah. Selain itu juga MC memiliki rencana setelah keluar dari LPKA, akan mendapatkan pekerjaan dan akan mendapatkan penghasilan. MC sangat optimis jika nanti setelah keluar dari LPKA dan mendapatkan uang akan mendirikan warung dan memulai usahanya sendiri, sehingga dapat membahagiakan orangtua.

Optimisme untuk melanjutkan sekolah dan mendapatkan pekerjaan setelah keluar dari LPKA juga dimiliki oleh informan TG. Informan sangat optimis jika nanti setelah keluar dari LPKA dapat melanjutkan sekolahnya kembali. TG meyakini dirinya akan segera dapat membantu kedua orangtuanya. Optimisme MC sudah dirancang dan di bayangkan dari sekarang dan tidak mempertimbangkan hal-hal negatif yang mungkin akan terjadi.

Informan RF memiliki keyakinan dalam menjalani masa hukuman dengan baik dan mengikuti aturan yang ada didalam LPKA. Hal ini menjadi tidak realistis mengingat banyak sekali kemungkinan RF melanggar peraturan di LPKA selama menjalani hukuman. Ajakan dan kemungkinan melanggar sangat didukung oleh lingkungannya seperti yang sudah terjadi. Sesuai dengan hal tersebut maka kemungkinan negatif yaitu melanggar memiliki peluang yang sama untuk terjadi. Optimisme informan RF adalah keyakinan dalam mengikuti peraturan di dalam LPKA dan bekerja setelah keluar dari LPKA. Optimisme yang dimiliki ini menjadi tidak realistis karena menurut RF kemungkinan gagal sangat kecil terjadi. Optimisme RF setelah keluar dari LPKA mencari pekerjaan apa saja dan mendirikan bengkel sendiri. Optimis Informan RF berlebihan sampai mengabaikan adanya kemungkinan setelah keluar sulit mencari pekerjaan dan kemungkinan kegagalan dalam mendirikan bengkel.

Optimisme yang dimiliki informan DD adalah keyakinan sukses setelah keluar dari LPKA. Menurut DD: "Optimis bisa sukseslah kak. Ustad Jefri aja bisa sukses". DD menyatakan sangat yakin kesuksesan dan mendapatkan istri yang cantik dapat diraih dengan melihat contoh yaitu Ustadz Jefri yang juga merupakan mantan narapidana dan dapat mencapai kesuksesan. DD melihat hal tersebut sebagai peluang unruk kesuksesan yang sama. Selama menjalani hukuman di dalam LPKA, DD yakin bisa menyelesaikan sekolah SMA dan yakin bisa diterima bekerja di kantor. Optimisme DD dalam mendapatkan pekerjaan diluar sana dan segera mendapatkan pasangan tidak diimbangi dengan kemungkinan dan peluang peristiwa negatif.

Lima Informan menyatakan optimisme dan menyampaikan tanpa mempertimbangkan adanya kemungkinan peristiwa atau peluang negatif yang muncul. Maka dari itu optimime tersebut menjadi Illusory Optimism. Disebut menjadi tidak realistis karena semua informan tidak mempertimbangkan bahwa kemungkinan gagal atau mengalami peristiwa negatif bisa saja terjadi. Informan RN berkata:

"Sebenarnya anak-anak disini bisa dikatakan sebagai anak yang hilang karena rata-rata orangtua mereka tidak peduli dengan mereka. Banyak anak didik yang tidak mendapat kunjungan dari orangtua, sehingga setelah keluar dari LPKA banyak dari mereka yang bingung harus bagaimana. Ada juga sih diantara mereka yang berhasil, karena masih diperhatikan orangtua tetapi lebih banyak yang kembali lagi bergaul dengan teman-temannya yang lama, malah ada yang residivis".

Pernyataan informan RN tersebut juga dibenarkan oleh informan AD dan LD. Pada saat ini belum ada program yang khusus untuk menangani $\mathrm{ABH}$ setelah menjalani proses 
rehabilitasi di Lembaga Pemasyarakatan. Setelah keluar dari LPKA, anak didik lebih cenderung langsung diserahkan kepada kelurga dan bagi anak yang tidak memiliki keluarga dibebaskan setelah menjalani masa hukuman yang ditetapkan tanpa pembebasan bersyarat. Kegiatan pengawasan tidak akan memberikan arahan optimal terhadap karir anak tersebut setelah bebas dari LPKA.

\section{Tabel 4 Illusory Optimism Informan}

\begin{tabular}{|c|c|c|}
\hline No & Informan & Illusory Optimism \\
\hline \multirow[t]{2}{*}{1.} & \multirow[t]{2}{*}{ EP } & Setelah keluar dari LPKA dapat langsung membuka bengkel dan berhasil \\
\hline & & Mendapatkan pekerjaan dan memiliki uang yang banyak \\
\hline \multirow[t]{2}{*}{2.} & \multirow[t]{2}{*}{$\mathrm{MC}$} & Memiliki kesabaran dan tetap menaati peraturan selama 6 tahun 6 bulan \\
\hline & & Sukses kerja setelah keluar dari LPKA dan mendapatkan banyak uang. \\
\hline \multirow[t]{2}{*}{3.} & \multirow[t]{2}{*}{ TG } & Langsung mendapat pekerjaan dan mudah dalam mencari uang. \\
\hline & & Langsung sekolah dan dapat ijazah dengan mudah sekaligus bekerja. \\
\hline \multirow[t]{3}{*}{4.} & \multirow[t]{3}{*}{ RF } & $\begin{array}{l}\text { Setelah keluar bekerja menjadi kuli bangunan dan mendapatkan uang } \\
\text { banyak. }\end{array}$ \\
\hline & & $\begin{array}{l}\text { Setelah keluar dapat langsung membuka bengkel dengan modal uang dari } \\
\text { bekerja sebagai kuli bangunan. }\end{array}$ \\
\hline & & Tidak akan melanggar peraturan di LPKA selama empat tahun. \\
\hline \multirow[t]{3}{*}{5.} & \multirow[t]{3}{*}{ DD } & Mendapat kerja dan sukses dengan mudah tanpa ijasah dari sekolah formal. \\
\hline & & Mendapatkan pekerjaan dan bekerja kantoran dengan mudah \\
\hline & & Mendapatkan istri cantic secepatnya. \\
\hline
\end{tabular}

Sumber: Hasil Penelitian Tahun 2020

\section{False Consensus for failings}

Manusia memiliki kecenderungan ingin tahu untuk meningkatkan gambaran diri dengan menganggap terlalu tinggi atau terlalu rendah luasnya pikiran orang lain dan tindakan yang kita lakukan. Saat kita berperilaku buruk atau gagal dalam suatu hal atau tugas, kita meyakinkan kembali diri kita dengan berfikir bahwa kegagalan suatu hal yang biasa. Contohnya ketika seseorang berbohong, dia akan mulai merasa orang lain tidak jujur. Mereka mengira orang lain berfikir dan bertindak juga sesuai dengan yang mereka lakukan. Terdapat dua kesalahan konsensus yang akan peneliti fokuskan, yaitu kesalahan konsensus terhadap kegagalan yaitu melakukan kejahatan dan kesalahan konsensus menjadi anak didik LPKA.

Infoman EP menyampaikan awal mula menjadi penyalahguna narkoba karena ajakan teman dan lingkungannya. Ini menjadi alasan bagi informan EP bahwa di luar sana (diluar lingkungannya) juga banyak orang yang menjadi pengguna dan bisnis narkoba, hanya saja tidak ketahuan dilindungi. EP menyatakan menjadi anak didik LPKA bukanlah hal yang umum dan juga tidak akan dipikirkan oleh orang lain. Karena masuk LPKA sama halnya seperti masuk kedalam penjara yang memiliki stigma negatif. Berdasarkan hal tersebut sehingga menurut EP menjadi anak didik LPKA bukanlah hal umum.

Infoman MC menyampaikan bahwa awal mula masuk dunia narkoba karena ajakan teman dan lingkungannya. MC menyampaikan banyak orang disekitarnya yang mnggunakan narkoba sehingga berfikir diluar sana juga pasti banyak juga. MC menyatakan banyak yang mengkonsumsi narkoba seperti misalnya artis dan pejabat. Hanya saja mereka tidak tertangkap. MC menunjukkan pandangannya yang sama bahwa berdasarkan realita yang mereka lihat 
mengkonsumsi narkoba adalah hal yang sudah menjadi lazim karena pengguna narkoba itu sangat banyak.

Menurut Informan MC menjadi anak didik adalah hal umum karena LPKA berbeda dengan penjara. Penghuni dari LPKA pada dasarnya anak nakal yang ditangkap. MC meyakini bahwa setiap anak pasti pernah nakal maka dari itu setiap anak juga bisa masuk LPKA kalau berbuat salah. MC menganggap masuk ke LPKA adalah hal yang biasa. MC juga mengatakan bahwa jumlah anak yang menghuni LPKA cukup banyak sehingga menjadi anak didik LPKA adalah hal umum.

Informan TG dengan kasus perkelahian dan pembunuhan yang dilakukan menyatakan bahwa perilaku kejahatan yang dialaminya tidak lazim dan memang bukan perilaku yang umum terjadi pada individu lainnya. Bahkan TG sendiri menyatakan tidak pernah terbayangkan akan melakukan pembunuhan. Pengeroyokan atau perkelahian yang dilakukan TG, menurutnya adalah hal yang umum dan banyak yang melakukan. Menjadi anak didik bukan hal umum, karena baginya seharusnya anak-anak tidak di kurung didalam LPKA. Menurutnya tidak ada anak yang ingin masuk kedalam LPKA karena hal itu bukan hal yang menyenangkan

Menurut RF pelecehan seksual yang dilakukannya adalah hal yang umum. RF sendiri menyatakan perilakunya hampir sama dengan seks bebas. RF memiliki pandangan bahwa seks bebas sudah terjadi dimana-mana. Banyak orang yang melakukannya sehingga perilakunya adalah hal umum. Menurut informan RF saat ini perilaku seks bebas sudah menjadi hal yang biasa dan banyak orang yang melakukannya. Apa yang dilakukannya adalah hal yang umum karena banyak yang melakukan. Angka jumlah perilaku seks bebas yang meningkat menjadi alasan RF mengatakan bahwa ini adalah hal umum. Hal ini menandakan bahwa RF memiliki konsesnsus bahwa seks bebas adalah hal umum dipikirkan banyak orang.

Sama halnya dengan TG, Informan RF menyatakan menjadi anak didik bukan hal umum, "kami kan ibaratnya ya disebut orang jahat. LPKA itu kan tempatnya anak-anak yang dianggap jahat kan kak. Ya pasti pada nggak mau jadi anak jahat". Pernyataan tersebut menegaskan bahwa menjadi anak didik LPKA bukanlah hal yang wajar dan umum bagi anak seusia TG.

Informan DD dengan kasus pembunuhan menyatakan bahwa perilaku kejahatan yang dialaminya tidak lazim dan memang bukan perilaku yang umum terjadi pada individu lainnya. Bahkan DD juga menyatakan tidak pernah berfikir melakukan tindakan tersebut. Informan DD menganggap bahwa pengeroyokan atau tawuran yang dialaminya bukan merupakan hal yang umum dilakukan orang. DD mengatakan jadi anak didik bukan hal umum, karena tidak ada yang mau jadi orang jahat.

Berdasarkan uraian pada aspek false consensus for failings terdapat dua hal yang di bahas yaitu terhadap kejahatan dan terhadap status anak didik. Terdapat beberapa perbedaan pada jawaban setiap informan. Dalam hal kasus terdapat dua orang yang menyatakan kejahatannya bukanlah hal yang umum dan tiga informan menyatakan kejahatan yang mereka lakukan adalah hal umum. Sedangkan dalam hal status anak didik satu informan mengatakan itu hal umum sedangkan empat informan lainnya menyatakan itu bukanlah hal yang umum. 
Tabel 5 False Consensus For Failings Informan

\begin{tabular}{|l|l|l|l|}
\hline No & Informan & \multicolumn{1}{|c|}{ Kasus yang dihadapi } & \multicolumn{1}{|c|}{$\begin{array}{c}\text { Hukuman Pembinaan } \\
\text { di LPKA }\end{array}$} \\
\hline 1. & EP & $\begin{array}{l}\text { Mengalami kesalahan karena menganggap } \\
\text { penyalahgunaan narkoba hal yang umum. }\end{array}$ & $\begin{array}{l}\text { Tidak mengalami kesalahan karena } \\
\text { menjadi anak didik LPKA bukanlah hal } \\
\text { umum dan bercitra buruk. }\end{array}$ \\
\hline 2. & MC & $\begin{array}{l}\text { Mengalami kesalahan karena menilai } \\
\text { penyalahgunaan narkoba hal yang umum. }\end{array}$ & $\begin{array}{l}\text { Mengalami kesalahan karena menganggap } \\
\text { menjadi anak didik/anak nakal wajar sama } \\
\text { halnya dengan anak diluar. }\end{array}$ \\
\hline 3. & TG & $\begin{array}{l}\text { Tidak mengalami Kesalahan karena } \\
\text { menganggap pembunuhan bukan hal } \\
\text { wajar. }\end{array}$ & $\begin{array}{l}\text { Tidak mengalami kesalahan karena } \\
\text { masuk ke LPKA sama dengan masuk } \\
\text { penjara yang berisi orang jahat. }\end{array}$ \\
\hline 4. & RF & $\begin{array}{l}\text { Mengalami Kesalahan menganggap } \\
\text { pelanggaran anak sama dengan seks bebas } \\
\text { dan banyak yang melakukan. }\end{array}$ & $\begin{array}{l}\text { Tidak mengalami kesalahan karena } \\
\text { menganggap LPKA berisi anak pelaku } \\
\text { kejahatan dan tidak ada anak yang mau } \\
\text { melakukan kejahatan. }\end{array}$ \\
\hline 5. & DD & $\begin{array}{l}\text { Tidak mengalami kesalahan karena } \\
\text { pembunuhan/tawuran/pengeroyokan } \\
\text { bukanlah hal yang umum. }\end{array}$ & $\begin{array}{l}\text { Tidak mengalami kesalahan karena } \\
\text { menjadi anak didik adalah hukuman dan } \\
\text { tidak ada dihukum dalam bentuk apapun. }\end{array}$ \\
\hline
\end{tabular}

Sumber: Hasil Penelitian Mahasiswa 2020

\section{Harapan Informan}

Apapun yang telah diperlakukan oleh $\mathrm{ABH}$ tidak akan merubah satu hal yaitu fakta bahwa mereka adalah anak-anak. Sebagaimana dalam kebijakan yang telah disusun oleh pemerintah bahwasanya mereka adalah termasuk golongan yang harus dilindungi hak- haknya. Mereka juga memiliki masa depan yang sama dengan anak-anak pada umumnya. Maka dari itulah peneliti memberikan kesempatan kepada informan $\mathrm{ABH}$ yang terlibat dalam penelitian ini untuk dapat menyampaikan harapan-harapannya. Kelima informan menyampaikan harapan:

\section{Tabel 6 Harapan Informan}

\begin{tabular}{|l|l|l|l|l|l|}
\hline \multirow{2}{*}{ No } & \multirow{2}{*}{ Informan } & \multicolumn{4}{|c|}{ Harapan } \\
\cline { 3 - 6 } & & Proses Peradilan & \multicolumn{1}{|c|}{ Petugas LPKA } & \multicolumn{1}{|c|}{$\begin{array}{l}\text { Orangtua/ } \\
\text { Keluarga }\end{array}$} & \multicolumn{1}{|c|}{ Diri Sendiri } \\
\hline 1. & $\begin{array}{l}\text { Keadilan dalam } \\
\text { menentukan vonis }\end{array}$ & $\begin{array}{l}\text { Menjadi orangtua } \\
\text { bagi anak didik }\end{array}$ & $\begin{array}{l}\text { Memaafkan } \\
\text { kesalahan EP. }\end{array}$ & $\begin{array}{l}\text { mengembalikan } \\
\text { uang orangtua }\end{array}$ \\
\hline 3. & MC & $\begin{array}{l}\text { Putusan hukuman } \\
\text { harus lebih adil. }\end{array}$ & $\begin{array}{l}\text { Lebih profesional } \\
\text { dan tegas. }\end{array}$ & $\begin{array}{l}\text { Lebih menyayangi } \\
\text { MC sebagai anak. }\end{array}$ & $\begin{array}{l}\text { Menjadi pribadi } \\
\text { lebih baik. }\end{array}$ \\
\hline 4. & RF & Penyidik lebih teliti & Harus profesional. & Menerima TG & Lebih baik \\
\hline 5. & DD & $\begin{array}{l}\text { Mendapatkan } \\
\text { keringanan }\end{array}$ & Lebih ramah & $\begin{array}{l}\text { Orangtua Sehat dan } \\
\text { memperhatikan RF. }\end{array}$ & $\begin{array}{l}\text { Menjadi diri sendiri } \\
\text { yang lebih baik. }\end{array}$ \\
\hline
\end{tabular}

Sumber: Hasil Penelitian Mahasiswa 2020 


\section{PEMBAHASAN}

Berdasarkan usia, Informan adalah remaja laki-laki berusia 17-18 tahun, melakukan pelanggaran hukum dan menjalani pembinaan di LPKA Kelas II Bandung. Satu informan berusia 18 tahun dan empat informan lainnya 17 tahun. Undang-Undang Nomor 11 tahun 2012 tentang Sistem Peradilan Pidana Anak menetapkan usia 12-18 tahun sebagai batasan usia anak berhadapan hukum. Pelanggaran hukum diusia tersebut mempunyai resiko yang tinggi dikarenakan anak masih dalam tahap perkembangan dan pertumbuhan.

Hurlock (1980) menyatakan bahwa pada masa remaja status individu tidaklah jelas karena bukan anak kecil namun juga belum dewasa maka terdapat keraguan akan peran yang harus dilakukan. Status ini menguntungkan karena memberi waktu menentukan gaya hidup yang berbeda, pola perilaku, nilai, dan sifat yang paling mereka inginkan. Apabila tidak mendapatkan arahan dan bimbingan yang baik, dalam tahap ini, anak mengalami keraguan diri. Pernyataan diatas menunjukkan bahwa perilaku pelanggaran hukum diusia remaja merupakan dampak dari keraguan diri. Anak ragu dalam menentukan peran sehingga anak cenderung untuk mencoba hal-hal baru. Hal tersebut sesuai dengan informan penelitian bahwa pelanggarannya dimulai dari mencoba hal baru. Kelima informan berasal dari keluarga utuh dan lengkap, memiliki saudara dan bukan anak tunggal. Kecuali MC, Informan lainnya tidak terlalu dekat dengan orang tuanya.

Hurlock (1980) menyatakan apabila selama masa remaja hubungan dengan anggota keluarga tidak harmonis, biasanya kesalahan terletak pada kedua belah pihak. Sebagian besar remaja merasa orangtua tidak cukup mengerti dirinya dan perilaku orangtua dianggap kuno dan tidak sesuai. Hal ini sesuai dengan pernyataan informan yang menyatakan kedekatan dengan orangtua dan keluarga menjadi renggang dan memilih untuk berada diluar rumah dikarenakan lebih merasa diterima dan dimengerti sesuai dengan keinginan anak.

Self serving attribution merupakan kecenderungan seseorang yang menghubungkan hasil positif atau keberhasilan untuk diri sendiri dan hasil negatif atau kegagalan pada hal lain diluar diri. Dalam konsep ini definisi kegagalan dan keberadilan diabaikan. Pandangan anak yang berhadapan dengan hukum keberhasilan merupakan sesuatu yang diperoleh karena adanya usaha yang dilakukan dengan kerja keras, sesuai dengan target yang diinginkan, bisa dipertahankan, bisa dilakukan dan mendapatkan hasil yang diinginkan. Sedangkan kegagalan adalah sesuatu yang dilakukan tanpa usaha, tidak bisa dilakukan, target yang diinginkan tidak tercapai, kurang beruntung, melanggar komitmen, dan akibat dari suatu kebodohan.

Informan menyampaikan faktor keberhasilan dan penyebab kegagalan mereka dengan mengatribusikan keberhasilan pada diri sendiri dan kegagalan pada faktor eksternal. Baron (2004) menjelaskan ada dua faktor yang mempengaruhi seseorang melakukan self-serving attribution yaitu faktor kognitif dan faktor motivasional. Faktor kognitif cenderung menginginkan kesuksesan berasal dari faktor internal daripada eksternal, sedangkan penjelasan motivasional menyatakan bahwa self serving atrribution didasari karena adanya kebutuhan untuk melindungi dan meningkatkan self-esteem sehingga berupaya untuk selalu tampil baik di depan orang lain. Pernyataan tersebut digunakan sebagai atribusi terhadap kesalahan yang anak lakukan demi melindungi self-esteem (harga diri) yang mereka jaga. Terdapat banyak motif yang muncul dalam perilaku bias dalam mengatribusi kegagalan atau kesalahan.

Bentuk membandingkan diri sendiri dengan orang lain pada $\mathrm{ABH}$ dapat dilihat dalam bentuk sopan santun selama berada di dalam LPKA. Etika dalam hal ini misalnya: menyapa 
petugas LPKA, melaksanakan apa yang disuruh oleh petugas, tidak berbicara kasar atau menyakiti hati teman dan sebagainya. Selain itu etika juga dalam hal berperilaku sehari-hari seperti tidak membully dan tidak mengganggu orang lain. Penelitian menunjukkan lima informan memiliki kecenderungan menilai bahwa dalam hal etika mereka lebih sopan di banding yang lain. Pada perbandingan tingkat intelegensi, informan lebih mengarahkan pada proses belajar di sekolah. Informan dalam penelitian ini menyatakan bahwa mereka mengikuti pelajaran dengan baik di sekolah dan mendapatkan nilai-nilai yang baik dibanding yang lain. Hal ini terlihat pada informan DD dan MC yang menyatakan bahwa mereka memiliki kecerdasan diatas yang lain dan menonjol dalam hal intelektual.

Perihal pelaksanaan ketertiban di dalam LPKA, lima informan menilai bahwa mereka patuh terhadap tata tertib. Lima informan menilai anak didik pemasyarakatan lainnya banyak yang terkena kasus yang lebih berat dibandingkan kejahatan yang mereka lakukan. Perbedaan hukuman disebabkan mereka memiliki uang untuk membayar pengacara atau hakim. Perilaku ini muncul karena adanya motivasi untuk dapat melindungi harga dirinya. Meskipun mereka adalah anak yang sedang mengalami masalah hukum, tetapi juga ingin memperlihatkan sisi baik mereka. Aspek ini berkenaan dengan bagaimana individu memandang dirinya dalam beberapa aspek jika dibandingkan dengan orang lain. Hal tersebut dilakukan atas dasar untuk melihat dan mengukur posisi individu dalam lingkungannya. Festinger dalam Myers (2012) menyatakan bahwa individu memberikan penilaian terhadap dirinya sendiri salah satunya dilakukan melalui perbandingan sosial, yaitu membandingkan diri sendiri dengan orang lain. Bentuk membandingkan diri sendiri dengan orang lain merupakan salah satu bentuk dari self serving bias. Tidak ada yang menginginkan dirinya dianggap rendah, bodoh, lemah, dan bodoh, lemah, dan bersalah dihadapan orang lain. Demikian juga halnya dalam pandangan anak yang berhadapan dengan hukum yang selama berada di LPKA ingin menampilkan dirinya sebagai anak yang baik dan mengikuti aturan yang berlaku di dalam LPKA.

Pandangan informan mengenai optimisme yang tidak realistis ini terlihat pada keyakinan anak yang berhadapan dengan hukum mendapatkan pekerjaan setelah keluar dari LPKA. Lima informan merasa yakin bahwa tanpa memiliki ijazah hal tersebut tidak akan menjadi hambatan bagi mereka untuk mendapatkan pekerjaan. Kenyataannya menurut pegawai LPKA Kelas II Bandung menyatakan bahwa banyak anak didik yang setelah keluar dari LPKA justru bingung dan merasa kesulitan untuk mendapatkan pekerjaan.

Baron \& Donn Byrne (2004) menyebutnya sebagai bias optimisme (optimistic bias) yaitu suatu predisposisi untuk mengharapkan agar segala sesuatu dapat berakhir dengan baik. Kecenderungan ini dapat dilihat dalam berbagai konteks yang berbeda yaitu anak berhadapan hukum percaya bahwa mereka memiliki kemungkinan yang lebih besar dari orang lain untuk mendapatkan pekerjaan yang baik, menikah, dan hidup hingga usia tua, namun kemungkinan kecil mengalami peristiwa negatif.

Penyebab anak berhadapan hukum melakukan illusory optimism adalah dikarenakan untuk menciptakan kondisi nyaman dan bahagia untuk saat ini. Selain itu guna menghibur diri yang saat ini sebenarnya masih dalam keadaan pesimis terhadap dirinya sendiri. Robinson \& Ryff dalam Myers (2012) menyatakan bahwa kebanyakan orang yakin bahwa dengan optimis akan menjadi lebih bahagia untuk masa sekarang dan masa depan.

Terdapat informan yang menyampaikan bahwa awal mula melakukan tindakan melanggar hukum adalah karena ajakan teman dan lingkungannya. Hal ini menjadi alasan bagi informan yang menyatakan bahwa di luar sana banyak orang yang melakukan kejahatan. Hal ini 
sejalan dengan teori yang disampaikan Dawes dalam Myers (2012) bahwa kesalahan konsensus ini bisa terjadi karena menggeneralisasikan sebuah sampel yang terbatas secara mencolok kepada diri kita.

Terdapat informan yang menyatakan menjadi anak didik LPKA bukanlah hal yang umum dan juga tidak akan terpikirkan oleh orang lain. Masuk LPKA sama halnya seperti masuk kedalam penjara yang memiliki stigma negatif. Akan tetapi terdapat juga informan yang berpendapat berbeda, menjadi anak didik adalah hal umum karena LPKA berbeda dengan penjara. Informan meyakini bahwa setiap anak pernah nakal. Banyak yang harus dibina LPKA sehingga menganggapnya hal ini adalah biasa. Sama halnya pendapat Dawes dalam Myers (2012) bahwa perilaku ini muncul dikarenakan menggeneralisasikan konsensus diri dan menggunakan respon pribadi sebagai tolak ukur terhadap respon orang lain.

Informan mempunyai harapan dalam proses persidangan agar Hakim memberi hukuman yang adil. Sejalan dengan harapan tersebut Hadisuprapto (2008) menyebutkan bahwa tinjauan dalam banyak hal telah meragukan dari sistem peradilan anak pada khususnya. Karena dalam hal tertentu proses peradilan seringkali membuat pelaku semakin parah saja kedudukan sosialnya. Khusus dalam peradilan anak sikap kehati-hatian dan pertimbangan terhadap masa depan anak sudah semestinya dikedepankan. Hal tersebut agar anak tidak menerima secara maksimal resiko peradilan yaitu stigma sosial.

Informan berharap agar petugas LPKA bersedia untuk mendengarkan pendapat dan masalah-masalah yang mereka hadapi dengan lebih bijak dan memberikan bantuan atas masalah yang dihadapi. ABH juga berharap orangtua memberi perhatian melalui kunjungan rutin di LPKA, sehingga anak tetap merasakan kasih sayang dan perhatian dari orang tuanya. Infoman memiliki harapan orang tuanya. Infoman memiliki harapan terhadap diri sendiri yaitu keinginan merubah perilaku yang tidak sesuai dan tidak mengulang kejahatan yang dilakukan, dan memiliki masa depan yang lebih baik setelah keluar dari LPKA. Pernyataan ini bahwa informan berharap dapat menjalani masa hukuman di dalam LPKA dengan baik dan memiliki masa depan yang lebih baik setelah dinyatakan bebas.

Penelitian menunjukkan adalah permasalahan terkait dengan perilaku self serving bias anak berhadapan dengan hukum di LPKA Kelas II Bandung. Permasalahan ini adalah adanya perilaku yang mengarah kepada gejala perilaku self serving bias maladaptif. Beberapa perilaku tersebut adalah tidak mengakui kesalahan yang dilakukan, menyalahkan setiap kegagalan/kesalahan kepada orang lain, merasa dicurangi dan menimbulkan rasa dendam, menilai dirinya lebih superior dan sombong, dan merasa tidak perlu merubah atau memperbaiki diri. Hasil diatas menunjukkan gejala yang dapat membahayakan anak itu sendiri apabila tidak diatasi. Apabila hal ini dibiarkan maka dapat mempengaruhi proses dan tujuan pembinaan terhadap anak selama berada di LPKA. Satu intervensi yang dapat dilakukan adalah dengan pendekatan Cognitive Behavioral Therapy (CBT). Pendekatan ini merupakan terapi psikososial untuk merubah pola pikir negatif menjadi positif sehingga prilaku maladaptif yang timbul akibat pola pikir yang salah akan berubah menjadi perilaku yang adaptif. Seseorang melakukan perilaku self-serving bias karena faktor kognitif dan faktor motivasional. Pendekatan CBT dapat meningkatkan kemampuan individu bereaksi secara adaptif dalam menghadapi masalah, kegagalan atau situasi sulit dalam fase hidupnya. Terapi ini meyakini bahwa manusia memiliki potensi untuk menyerap pemikiran rasional dan irasional, dimana pemikiran yang irasional dapat mengganggu emosi dan tingkah laku. Maka dari itu proses CBT diarahkan pada modifikasi fungsi berpikir, merasa, dan bertindak dengan menekankan peran otak dalam menganalisa, 
memutuskan, bertanya, bertindak, dan memutuskan kembali. Setelah merubah status pemikiran dan perasaan individu diharapkan dapat merubah tingkah lakunya.

Intervensi CBT ini dapat menjadi layanan yang masif dan komprehensif terhadap permasalahan Self Serving Bias anak berhadapan hukum di LPKA Kelas II Bandung. Selain itu juga, tujuan dari pendekatan ini adalah untuk mengubah pemikiran dan keyakinan disfungsional yang bersifat negatif sehingga mampu menganalisis bahwa penyebab kegagalan yang dialami bukan hanya disebabkan faktor ekstemal tetapi juga internal, meningkatkan kemampuan anak dalam menganalisis dan mengembangkan altematif pemecahan masalah yang lebih adaptif sehingga mampu menghadapi situasi sulit dengan cara yang lebih tepat dan bertanggung jawab terhadap keputusan yang dibuat, serta meningkatkan rasa tanggung jawab pada individu dalam menghadapi kegagalan atau peristiwa negatif yang dialami.

\section{KESIMPULAN}

Penelitian ini bertujuan untuk mengetahui bentuk-bentuk self serving bias pada anak berhadapan dengan hukum, yaitu kecenderungan menilai dirinya secara positif dan menyalahkan orang lain atau situasi atas kegagalan yang dihadapinya. Hasil penelitian menunjukkan bahwa pada aspek self serving attribution seluruh informan melakukan perilaku tersebut dengan mengatribusikan hal positif pada diri sendiri dan hal negatif pada faktor eksternal. Pada aspek Self Congratulatory Comparison seluruh informan juga melakukannya dengan membandingkan dirinya lebih positif dibanding anak yang lain dalam hal etika, intelegensi, ketertiban, ibadah, kasus yang dihadapi, dan lama hukuman. Sama halnya pada aspek illusory optimism seluruh anak mengabaikan adanya kemungkinan negatif yang ada pada setiap harapan-harapan yang mereka miliki. Demikian pula pada aspek false consesnsus for failings terdapat beberapa anak yang menganggap bahwa pelanggaran hukum yang mereka lakukan dan menjadi anak didik di LPKA adalah suatu hal yang wajar dan umum menurut konsensus mereka. Berdasarkan gejala perilaku yang muncul perilaku self serving bias yang muncul merupakan perilaku self serving bias maladaptif.

Berdasarkan hasil analisis masalah yang terjadi pada setiap aspek Self Serving Bias, maka kebutuhan-kebutuhan yang diperlukan oleh anak berhadapan hukum dalam menangani self serving bias adalah perlunya penanganan terbaik pada anak dengan prinsip kerahasiaan dan dengan didukung pelibatan orangtua, peningkatan konsistensi dan kedisiplinan petugas, serta perancangan program pasca pembinaan. Dalam konteks praktik pekerjaan sosial, dapat dilaksanakan melalui penerapan Metode Praktik Pekerjaan Sosial Individu dan keluarga (Social Case Work) dan Metode Pekerjaan Sosial dengan Kelompok (Social Group Work).

Melalui Metode pekerjaan sosial dengan individu dan keluarga dapat diterapkan berbagai teknik seperti Cognitive Behaviour Therapy agar anak berhadapan hukum mampu mengatasi berbagai permasalahan sehingga dapat mengontrol diri dalam melakukan self serving bias menjadi adaptif. Alasan memilih bentuk terapi ini adalah bahwa sesuai dengan teori yang sejalan dengan hasil penelitian menunjukkan bahwa perilaku self serving bias erat kaitannya dengan kondisi kognitif yang mempengaruhi perilaku dimana penyebab perilaku ini adalah kognisi dan motivasi.

Kondisi anak berhadapan hukum memiliki latar belakang yang berbeda-beda dalam kondisi kognitif, sehingga diperlukan terlebih dahulu penanganan yang dapat mempersiapkan anak untuk menerima intervensi dengan Cognitive Behaviour Therapy. Teknik metode Pekerjaan sosial yang dapat mempersiapkan kondisi anak adalah dengan metode kelompok dengan jenis kelompok terapeutik untuk meningkatkan kondisi 
kognitif anak. Teknik ini bertujuan meningkatkan kemampuan diantaranya kognitif, moral, psikososial, dan emosional sehingga anak siap mendapatkan intervensi Cognitive Behaviour Therapy.

\section{DAFTAR PUSTAKA}

Baron, Robert A. \& Donn Byrne.2012. Psikologi Sosial. Jakarta: Penerbit Erlangga.

CharlotteA.Newey.2016. Fairness as "Appropriate Impartiality and the Problem of the Self-Serving Bias". Ethic Theory Moral Prac.19:695-709. DOI10.1007/s10677-015-9665-6

Feri Fernandes.2014. Penerapan Terapi Kelompom Terapeutik Dalam Menstimulasi Perkemabangan Remaa Dengan Pendekatan Model Stress Adaptasi Stuart dan Promosi kesehatan. Jakarta: Penelitian FIK UI

Corey, Gerald. Corey Mariana Schneider. Dkk. 2011. Teknik Kelompok. Bandung: STKS Press

Hadisuprapto, Paulus.2008. Delinkuensi Anak: Pemahaman dan Penanggulangannya. Malang: Bayumedia Publisher.

Hepworth, Dean H. \& Jo Ann.2008. Direct Social Work Practice: Theory and Skill. $8^{\text {th }}$ Edition. California: Brooks/Cole Publishing Company.

Hurlock, Elizabeth B.2018. Psikologi Perkembangan. Jakarta: Erlangga.

Jacob, Ed. E Dkk.2008. Konseling Kelompok: Strategi dan Keahlian. Jakarta : Pustaka Societa.

Joseph P.Ryan, AbigailB.Williams, Mark E.Courtney.2013. Adolescent Neglect, Juvenile Delinquency and the Risk of Recidivism. J Youth Adolescence. 454:456. DOI10.1007/s10964-013-9906-8

Kasandra Oemarjoedi.2003. Pendekatan Cognitive Behavior dalam Psikoterapi. Jakarta: Creative Media
Kim.2009. Self-serving and group-serving bias: Comparative analyysis of Japanese, Korean, and US results. Asian Journal of Social Psychology.

Maryatun, Sri.2014. Pengaruh Terapi Kelompok Therapeutic Terhadap Perkembangan Remaja Di Panti Sosial Marsudi Putra Dharmapala Inderalaya. Jurnal Keperawatan Jiwa Volume 1. ISSN No 23555459

Mather, Jannah Hum \& Patricia B. Larger.2000. Child Welfare: A Unifiying Model of Pracitice. United States: Wadsworth

Moleong, Lexy J.2012. Metodologi Penelitian Kualitatif. Bandung: PT. Remaja Rosdakarya

Mohd.Shakil.2015. Criminal Justice System: Social Work And Corrections. International Journal of Society and Humanities. Vol6/2015No-1/ISSN-2319-2070

Myers, David G.2012. Psikologi Sosial Jidid 1. Jakarta: Salemba Humanika .2012. Psikologi Sosial Jilid 2.

Jakarta: Salemba Humanika .2013. Social Psikologyl Eleventh Edition. United States of America: McGrawHill Company

Patterson, Goerge T.2012. Social work practice In The criminal Justice System. USA and Canada: Roudledge Taylor \& Francis Group.

Purniati, Dkk.2003. Analisa Situasi Sistem Peradilan Pidana Anak (Juvenile Justice System) di Indonesia. UNICEF Indonesia.

Posey, Elisabeth.2003.The Self Serving Bias In Childern. Psi Chi Journal Of Undergraduate Research: National Honor Society In Psicologhy. Volume 8 No.4 153-156. ISSN No. 10894136.

Siegel, Larry J and Welsh, Brandon C.2014. Juvenile Delinquency: The Core International Edition. $5^{\text {th }}$ Edition. United Stated : Wadsworth.

Susilowati, E. (2017). Kompetensi Pekerja Sosial dalam Pelaksanaan Tugas Respon Kasus Anak Berhadapan dengan Hukum di Cianjur. Pekerjaan Sosial, 16(1). 
(2018). Knowledge and Skills of Social Workers in Handling Children in Conflict with Law in Indonesia. Asian Social Work Journal, 3(4), 1-12.

Yana Sundayani.2015. Pengantar Metode Pekerjaan Sosial. Bandung: STKS Press. 